\title{
THE MITHRAEUM AT KEMPRATEN (CH) - PRELIMINARY RESULTS FROM A NEW DISCOVERY IN 2015/16
}

\begin{abstract}
Summary: During rescue excavations carried out near the vicus at Kempraten (municipality of Rapperswil-Jona, St. Gallen, Switzerland) in advance of a private construction project, a Mithraeum measuring approximately 8 by $10 \mathrm{~m}$ was unexpectedly discovered in the summer of 2015 and subsequently excavated and investigated in detail. This paper presents the preliminary results of the excavation, which was completed less than a year ago, and pays particular attention to the interdisciplinary approach used in the excavation. These included intense sampling of the features for the purposes of micromorphology and archaeobiology. Three construction phases with intermittent conflagrations were identified. The question as to whether there was an ante-chamber remains unanswered. The external areas are also quite difficult to interpret, at least for the time being. The rich assemblage of finds, which included numerous coins, pottery, animal bones and a range of religious artefacts (e.g. altars and a half relief), will only be dealt with in a cursory manner here. According to the range of coins, the Mithraeum undoubtedly dated from the late 3 rd to the late 4 th or early 5 th centuries. The site will be analysed by an interdisciplinary team and preliminary work is already underway.
\end{abstract}

Key words: Switzerland, Germania superior, excavation methods, sampling strategy, vicus, Mithraeum, archaeological science, archaeology, Roman Imperial period, cult, religion

\section{INTRODUCTION}

The Kempraten vicus was uncovered in the north-western part of what is today the town of Rapperswil-Jona (Canton St. Gallen) located on the northern shore of Lake Zurich. In recent years Rapperswil-Jona has experienced intense building activity. For the past approximately ten years, the Archaeology Department of Canton St. Gallen (KASG) has been able to systematically mount rescue excavations in advance of planned construction projects. As a result, our knowledge of the vicus has significantly increased within a short space of time and it has been possible to unearth such unexpected finds as the Mithraeum discussed here. 
The Roman settlement spread over an area of at least 11 ha lining various transport routes. ${ }^{1}$ The fact that water and land routes criss-crossed at this point made the area interesting as a place of settlement, once the road which branched off from the east-west-axis (Graubünden passes - Vindonissa - Gaul/Germania) to the north towards Vitudurum and the Danube border had become more important. The settlement was founded in around AD 30/40. Not much is known about the first settlement, except that it comprised several timber-built phases which were replaced in around AD 120 by stonebuilt constructions. Based on the coin sequence, the Roman settlement can be shown to have lasted until the turn of the 5th century AD. Whilst its transition to the Early Middle Ages remains unexplored, we may assume that the settlement continued. ${ }^{2}$

A forum, of which an exedra (perhaps a curia or temple?) and another monumental building in front of it (perhaps a basilica?) are known, and whose architecture was surprisingly monumental given the type of settlement it was and the region in which it stood, formed the centre of the settlement (fig. 1). ${ }^{3}$ The streets in the residential districts close to the centre were lined with large complex buildings of a high-quality finish, some of which had interior courtyards. Smaller buildings which were as carefully constructed but had only one or two rooms, stood in the back yards of these edifices. ${ }^{4}$ A district with strip houses was unearthed in the northern part of the settlement. The back yards of these strip houses contained workshops, notably potters' workshops (fig. 1, Fluh). ${ }^{5}$ A Magna Mater sanctuary with two Gallo-Roman temples enclosed by a temenos was discovered on the north-western edge of the settlement (fig. 1, Seewiese). ${ }^{6}$

The property at Zürcherstrasse 131 is located directly on Lake Zurich and c. $200 \mathrm{~m}$ from the Seewiese temple district, which means that in Roman times the site would have been situated outside the actual settlement (fig. 1, Zürcherstrasse 131). ${ }^{7}$ The area is characterised by a rocky outcrop with an upper flat terrace, a rather steep slope and a lower terrace. The latter also had a steep slope which, however, had been filled with sediment since the Last Ice Age, most of which now lies below the lake level. ${ }^{8}$ The Roman-period shoreline, however, has not survived due to modern alterations. Much like today, the lake level during the Roman period was at approx. $406 \mathrm{~m}$ a.s.1. ${ }^{9}$

\footnotetext{
${ }^{1}$ Not included in the 11 ha is the only known cemetery in the Belsito area and the site of the Mithraeum itself, since it is presumed that it was strictly speaking located outside of the settlement.

${ }^{2}$ ACKERMANN, R.: Der römische Vicus von Kempraten, Rapperswil-Jona. Neubetrachtung anhand der Ausgrabungen Fluhstrasse 6-10 (2005-2006) [Archäologie im Kanton St.Gallen 1]. St. Gallen 2013, $216 \mathrm{ff}$.

${ }^{3}$ MATter, G.: Jona SG, Kempraten, Parzelle 4239, Grabung 2002. Ein repräsentativer Architekturkomplex im Zentrum des römischen Vicus Kempraten. Jahrbuch der Schweizerischen Gesellschaft für Ur- und Frühgeschichte 86 (2003) 178-185; ACKERMANN (n. 2) 214-215.

${ }^{4}$ ACKERMANN (n. 2) 211-215.

${ }^{5}$ JbAS 92 (2009) 306f., JbAS 93 (2010) 253f. and JbAS 95 (2012) 194f.

${ }^{6}$ See the article by Pirmin Koch in this volume, DOI: 10.1556/068.2018.58.1-4.34.

${ }^{7}$ Excavation Rapperswil-Jona SG, Kempraten, Zürcherstrasse 131, site no. 53.204; JbAS 99 (2016) 206f.; JbAS 100 (2017) 241f.

${ }^{8}$ We would like to thank Thomas Gubler, Schwändi near Schwanden, and Hugo Mändli, Horgen, for assessing the geological situation.

${ }^{9}$ (Note: a.s.1 = above sea level). WILD, D.: Der Befund. In WILD, D. - KREBS, D. (eds): Die römischen Bäder von Zürich. Ausgrabungen am Weinplatz in der Altstadt von Zürich 1983/84 [Berichte der
} 


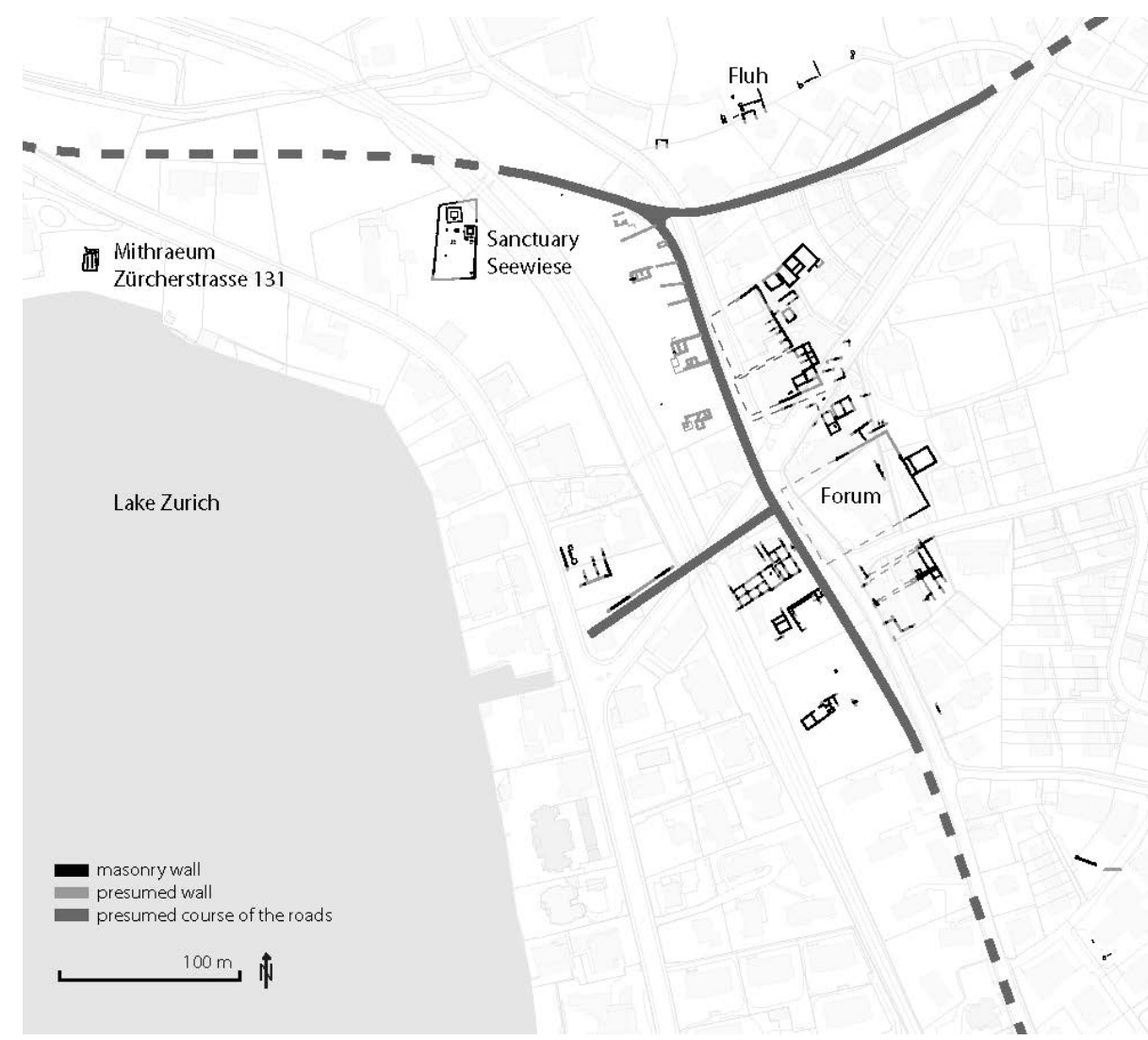

Fig. 1. Rapperswil-Jona, Kempraten: Overall map of the vicus in the 2 nd/3rd centuries AD (sc. 1:5000, map: KASG)

Geological trial trenches dug for the purposes of foundation testing in January 2015 exposed two Roman lime kilns. This prompted the Archaeology Department to carry out a geomagnetic survey of the area that would be affected by the planned construction project and that had previously been used as meadowland. The aim was to ascertain the number of kilns and potential other structures prior to the commencement of the rescue excavation, which would now be mounted. The results suggested the existence of another kiln and pinpointed a further area as worth investigating. ${ }^{10}$

Zürcher Denkmalpflege. Monographien 24]. Zürich/Egg 1993, 23 and 25; EBERSCHWEILER, B. - KÄCH, D.: Ein römischer Rundtempel auf dem Großen Hafner im Zürichsee. In Archäologie im Kanton Zürich 2003-2005. Bericht 18. Zürich 2006, 249; WILD, D.: Lindenhof, Sihl und Zürichsee - Fragen zu Geologie und Topographie zwischen Spätlatène und Frühmittelalter. In BALMER, M. (Hrsg.): Zürich in der Spätlatène- und frühen Kaiserzeit. Vom keltischen Oppidum zum römischen Vicus Turicum [Monographien der Kantonsarchäologie Zürich 39]. Zürich/Egg 2009, 17.

${ }^{10}$ HÜBNER, C.: Bericht 464/2015: Geophysikalische Prospektion Zürcherstr. 131 (53.204) Rapperswil-Jona, Kempraten (Kanton St.Gallen, Schweiz). Unpublished manuscript. Freiburg i. Br. 2015 (records in the KASG archive, site no. 53.204). 


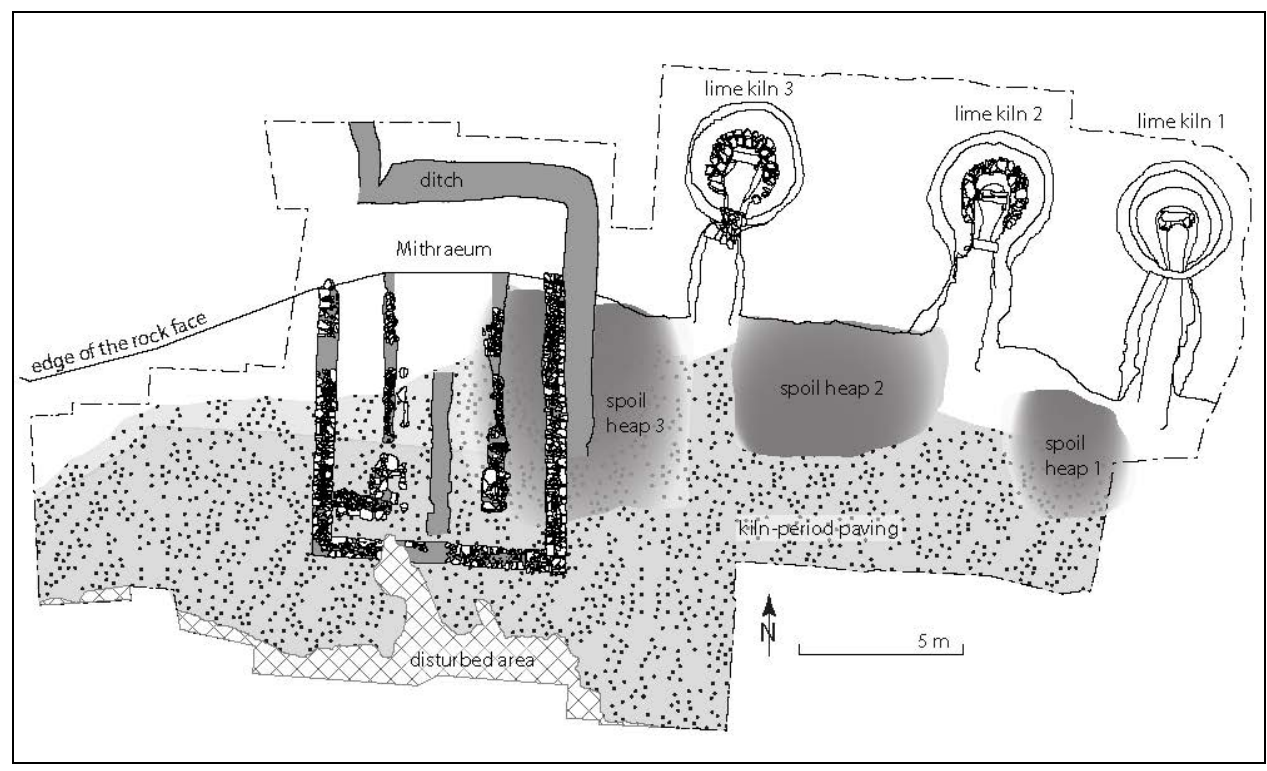

Fig. 2. Rapperswil-Jona, Kempraten: Overall map of the excavation at Zürcherstrasse 131 with the Mithraeum, three lime kilns and their associated spoil heaps as well as the excavation perimeter (sc. 1:300, map: KASG)

Soon after commencement of the rescue excavation it became obvious that the Roman builders had availed of the natural slope in the terrain for the construction of three adjacent lime kilns in that both the praefurnia and kilns were hewn into the rock (fig. 2). The lower terrace was fortified with loose paving and the resulting, rather large square served as a work space and increasingly as a dumping ground for the spoil from the kilns. ${ }^{11}$

It was not until the end of the planned excavation that the eastern external wall (MR1) of a Mithraeum came to light west of the kilns in the area that had been pinpointed by the geomagnetic survey. A trench dug at right angles to the wall brought to light two lateral platforms and a central aisle. The finds recovered included numerous coins, animal bones, almost exclusively of poultry, and a number of rock crystals, immediately pointing to a possible religious function for the building. Any residual doubts were removed and it became apparent that the features had to be the remains of a Mithraeum when two fragments of a larger than life-sized cult image depicting Mithras were discovered a short time later (fig. 3).

The extraordinary find - it is only the third building of its kind to come to light in present-day Switzerland ${ }^{12}$ - led to the excavation being extended to the end of

${ }^{11}$ On the lime kilns, see ACKERMANN, R. - Koch, P.: Römische Kalkbrennereien im Vicus von Kempraten (Rapperswil-Jona SG). Minaria Helvetica 36 (2015) 78-80.

${ }^{12}$ The other two Mithraea are located at Martigny/Forum Claudii Vallensium, Canton Valais (WIBLÉ, F.: Martigny-la-Romaine. Martigny 2008, 146-166) and Orbe, Canton Vaud (MONNIER, J.: Un dieu d'origine orientale: Mithra. In LuginbÜHL, T. - MonNier, J. - Dubois, Y. (eds): Vie de palais et 


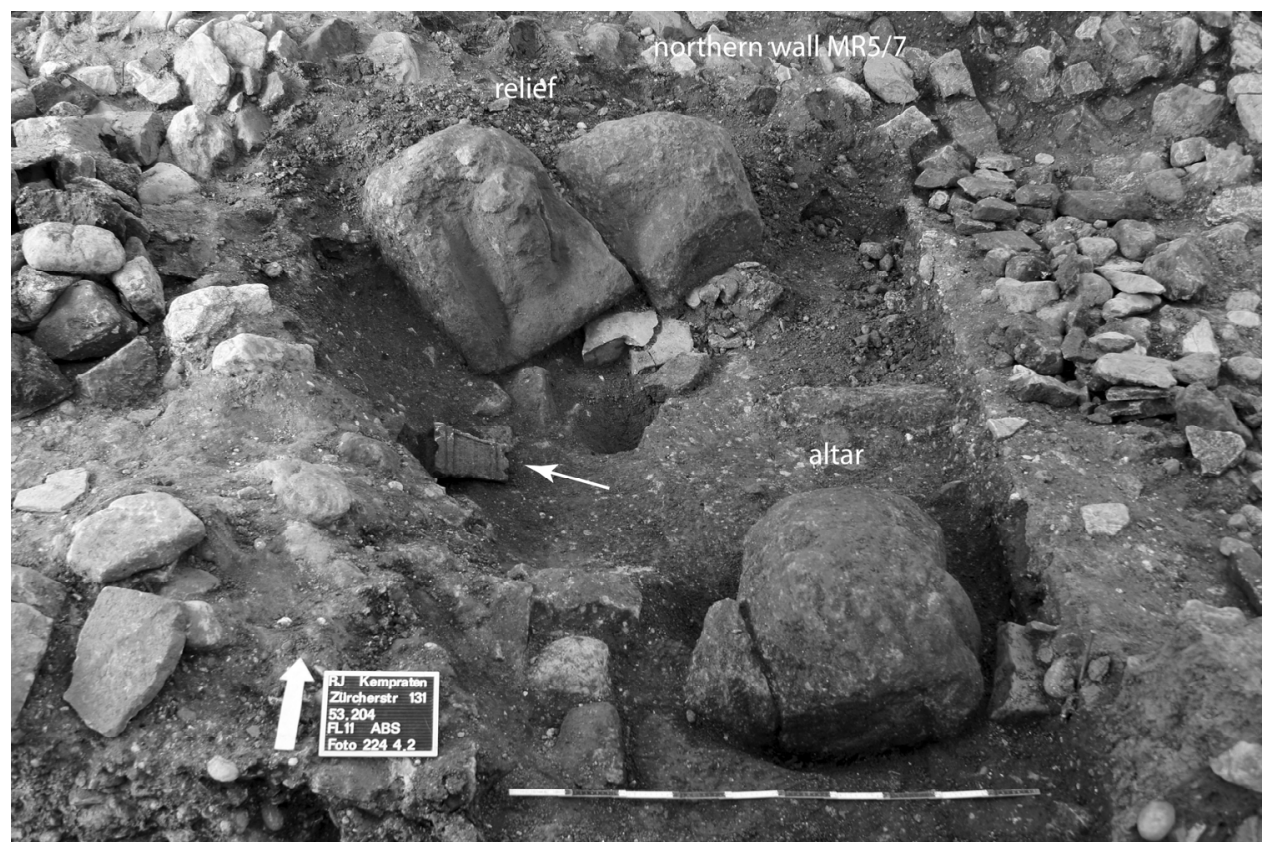

Fig. 3. Rapperswil-Jona, Kempraten, Zürcherstrasse 131, Mithraeum Phase 3: Northernmost area of the central aisle with two large fragments of a sandstone cult image in the background and a small steatite altar with a dedication to Mithras (arrow) together with a fragment of a large sandstone altar in the foreground. View towards the north (photo: KASG)

February 2016. This in turn meant that a winter excavation with all its associated difficulties had to be carried out. The finds and features had to be protected from the weather, including rain and snow as well as frost. Recognising the features was harder during the darker months and this was compounded by the fact that the layers inside the Mithraeum were very dark to begin with, due to the charcoal left behind by several incidents of fire. It was also important to apply adequate excavation methods given the special nature of the feature (see chapter 2 ).

Because the excavation was completed just a few months ago, we can only present preliminary results here. ${ }^{13}$ The post-excavation work is still ongoing, as is the processing of the samples and finds. We plan to carry out an interdisciplinary study

travail d'esclave. La villa romaine d'Orbe-Boscéaz. Document du Musée cantonal d'archéologie et d'histoire de Lausanne. Lausanne 2001, 92-96; LuginBüHL, T. - MONNIER, J. - MüHLEMANN, Y.: Le mithraeum de la villa d'Orbe-Boscéaz (Suisse): du mobilier aux rites. In MARTENS, M. - DE BoE, G. (eds): Roman Mithraism: The Evidence of the Small Finds, Tienen 7-8 November 2001 [Archeologie in Vlaanderen. Monografie 4]. Brussels 2004, 109-133; MONNIER, J.: Le mithraeum. In PAUNIER, D. - LUGINBÜHL, T. (eds): La villa romaine d'Orbe-Boscéaz. Genèse et devenir d'un grand domaine rural. Volume 1: Environnement, histoire et développement du bâti [Cahiers d'Archéologie Romande 161]. Lausanne 2016, 278-326.

${ }^{13}$ This manuscript was submitted in the very beginning of 2017. 
using micromorphological, archaeobiological, numismatic and epigraphic methods, and the preparatory work has already begun. ${ }^{14}$

\section{RESEARCH QUESTION AND SAMPLING STRATEGY}

The discovery of the Mithraeum raised a wide range of questions that could potentially be answered by this specific feature, and these in turn influenced the choice of excavation methods and sampling strategy. The first goal, of course, was to trace the construction history of the building, including its potential phases of alteration and their causes. Another aim was to study the interior structure of the building - the division into an ante-chamber and a sacred space - and gather as many clues as possible with regard to its furnishings. The excavation methods also had to allow for investigations of the horizontal stratigraphy of the artefacts within the sacred area. This was of particular interest in view of the hierarchy that is known to have existed among the initiates of Mithraism and with regard to the potential allocation of reclining benches on the platforms. The final aim was to gather as much evidence as possible of the rites and banquets held at the Mithraeum. The Kempraten site also allowed us to excavate the sanctuary's environs. Here the aim was to ascertain whether the cult area had been enclosed or delimited and whether there had been ritual pits and other zones whose use could be linked with the Mithraeum.

The Archaeology Department of Canton St. Gallen generally uses a featurebased system of documentation (assigning a specific number to each deposit or feature). The finds are recovered and labelled according to their stratigraphical position or associated feature. In this case, the features and deposits in the areas of the platforms and the central aisle were further divided into quarter square metres for the purpose of recovering the finds and taking samples. This was done to facilitate the investigation of the horizontal stratigraphy in particular. The sediments were systematically sieved on site so that even minute finds could be retrieved. In addition, the precise positions of the coins, clay balls with incised numbers, boars' tusks, rock crystals and other small finds were recorded with the aim of creating detailed distribution maps.

Inside the Mithraeum at least one sediment sample was taken for archaeobiological examination from at least one quarter square metre of every square meter of occupation layer removed. The samples will be wet-sieved using the wash-over method in order to gather botanical and zoological remains. ${ }^{15}$ Along with the hand-

14 The enormous potential of interdisciplinary approaches including natural scientific methods has clearly been seen in the extensive work that has already been done on the Magna Mater sanctuary at Kempraten under the direction of Pirmin Koch (Archaeology Department of Canton St. Gallen and Cologne University); see his article in this volume, DOI: $10.1556 / 068.2018 .58 .1-4.34$.

${ }^{15}$ On the potential of archaeobotanical analyses, particularly of samples from religious contexts, see for example VANDORPE, P. - JACOMET, S.: Remains of burnt vegetable offerings in the temple area of Roman Oedenburg (Biesheim-Kunheim, Haut-Rhin, Alsace). First results. In WIETHOLD, J. (éd.): Carpologia. Articles réunis à la mémoire de Karen Lundström-Baudais. Actes des rencontres d'archéobotanique organisées par Bibracte, Centre archéologique européen et le Centre de Recherches Archéologiques de la Vallée de l'Oise, 9-12 juin 2005. Glux-en-Glenne 2011, 87-100. On the subject of archaeo- 
retrieved animal bones, the remains from the samples will potentially allow us to reconstruct the meals that were served during the religious feasts. Moreover, they can provide evidence regarding sources of light (fatwood) and information on the environment and landscape. The archaeobiological remains can, furthermore, be examined with regard to the horizontal stratigraphy which might allow us to draw conclusions concerning the individual reclining benches or ritual acts.

Polished and thin sections taken from oriented soil columns for micromorphological analyses cover almost the entire stratigraphical sequence within the Mithraeum and selected layer sequences outside the sanctuary. ${ }^{16}$ The analysis of the thin sections will provide information on the formation of the layers. ${ }^{17}$ Particular attention will be paid to the occupation surfaces with the aim of gathering evidence pointing to floor constructions (e.g. floor boards) as well as incidents of demolition or alteration work. Another question is the construction of the surfaces of the reclining benches. Depending on the state of preservation there is a possibility that textiles might even be identified in some of the thin sections.

\section{FEATURES}

When the Mithraeum was built, the location of the lime kilns at the foot of the slope was covered in part by spoil heaps and in part by rather extensive talus deposits, whilst in other areas the kiln-period paving ${ }^{18}$ on the terrace at the foot of the slope may still have been usable (fig. 2). The uneven terrain was not levelled by the builders of the Mithraeum. On the contrary: measuring some 8 by $10 \mathrm{~m}$, the planned three-aisled building made use of the topographical situation and the sanctuary's exterior layout was adapted to fit into the terrain.

The cliff face in the northern area of the site was hewn into several times to extend the Mithraeum. This created a sediment trap with the most complete layer preservation and thickest post-Roman deposits. The state of preservation deteriorated towards the south - following the natural course of the terrain towards the lakeshore and only a single course of stones of south wall MR6 survived. Water was still seeping from the rock during the excavation, leading to the bottommost layers in the

\footnotetext{
zoological analyses, cf. e.g. OLIVE, C.: La faune exhumée des mithraea de Martigny (Valais) et OrbeBoscéaz (Vaud) en Suisse. In Roman Mithraism (n. 12) 147-156; DESCHLER-ERB, S.: Tier und Kult. Spezielle Tierknochendeponierungen der Spätlatène- und Römerzeit aus Aventicum/Avenches (CH) im nordalpinen Vergleich [Documents du Musée Romain d'Avenches 27]. Avenches 2015; GINELLA, F. - HÜSTER-PlogmAnN, H. - SCHIBleR, J.: Die Tierknochen. In ReDDE, M. (éd.): Oedenburg. Les fouilles françaises, allemandes et suisses à Biesheim et Kunheim, Haut-Rhin, France. Volume 2: L'agglomération civile et les sanctuaires [Monographien des Römisch-Germanischen Zentralmuseums 79/2]. Mainz 2011, 103-195.

${ }^{16}$ Pollen samples will also be taken from these soil columns.

${ }^{17}$ Micromorphological analyses were carried out e.g. at the Biesheim Mithraeum, where they yielded essential results; RENTzEL, P.: Spuren der Nutzung im Mithraeum von Biesheim. Mikromorphologische Untersuchungen. In Oedenburg. Vol. 2 (n. 15) 248-255.

${ }^{18}$ Pos. 363.
} 
Mithraeum exhibiting wetland preservation. However, the stratigraphy was drylandpreserved for the most part.

At this stage of the investigation, three construction phases can be identified from the architectural remains of the Mithraeum and these will now be presented.

\subsection{The construction of the Mithraeum - Phase 1}

The Mithraeum was built on a north to south axis with the northernmost area of the sacred space hewn into the rock (fig. 4, Phase 1). The external south wall MR6 and the southernmost section of the lateral walls MR1 and MR2 were built without foundations directly onto the kiln-period terrace or its occupation layers. In the northern area of the site the kiln-period occupation layers and waste deposits as well as the bedrock itself were covered with loose sediment of natural or anthropogenic origin, which meant that prior to construction of the Mithraeum's external walls the deposits had to be removed down to the bedrock, the kiln-period paving or the overlying kilnperiod occupation layers. The east wall MR1 was dug into kiln-period spoil heap 3 and had several layers of foundations in this area. An actual wall pit (labelled NPos. 666 on the inside and NPos. $285^{19}$ on the outside) was therefore only identified in the sections of MR1 that had foundations.

The dimensions of west wall MR2 and east wall MR1 and the fact that a cavity was hewn out of the rock for the central aisle and the retaining walls of the platforms (NPos. 842 and NPos. 841) suggest that the original northern end of the building coincided with the presumed kiln-period cliff edge. The north wall probably sat on this rock podium, although it was later completely demolished and thus could no longer be identified in situ. It remains unknown whether and to what extent the rock face remained visible in the north, particularly in the area of the central aisle.

As is typically seen in Mithraea, the building was divided internally into a central aisle situated at a lower level, and slightly raised, lateral reclining benches. There was no division identified between an ante-chamber and a sacred space (spelaeum). The ante-chamber may have been a lighter construction located to the south of the stone building and perhaps did not survive due to its poorer state of preservation.

Prior to construction of the platform retaining walls and the central aisle, all layers had been removed down to the last remnants of the kiln-period paving, or more often even down to the bedrock (NPos. 842, NPos. 841). In addition, the rock surface was removed in the northern part of the central aisle, thereby levelling the natural rise in the terrain to a certain extent. A shallow drainage channel running north to south (NPos. 945) was carved out of the rock in the middle of the aisle, which collected the water that was seeping out of the slope and drained it through a gap in

\footnotetext{
${ }^{19}$ The bottom part of NPos. 285, the actual foundation trench, was backfilled after construction of the sanctuary, whilst the upper part remained open during use of the building; see Chapter 3.4.
} 

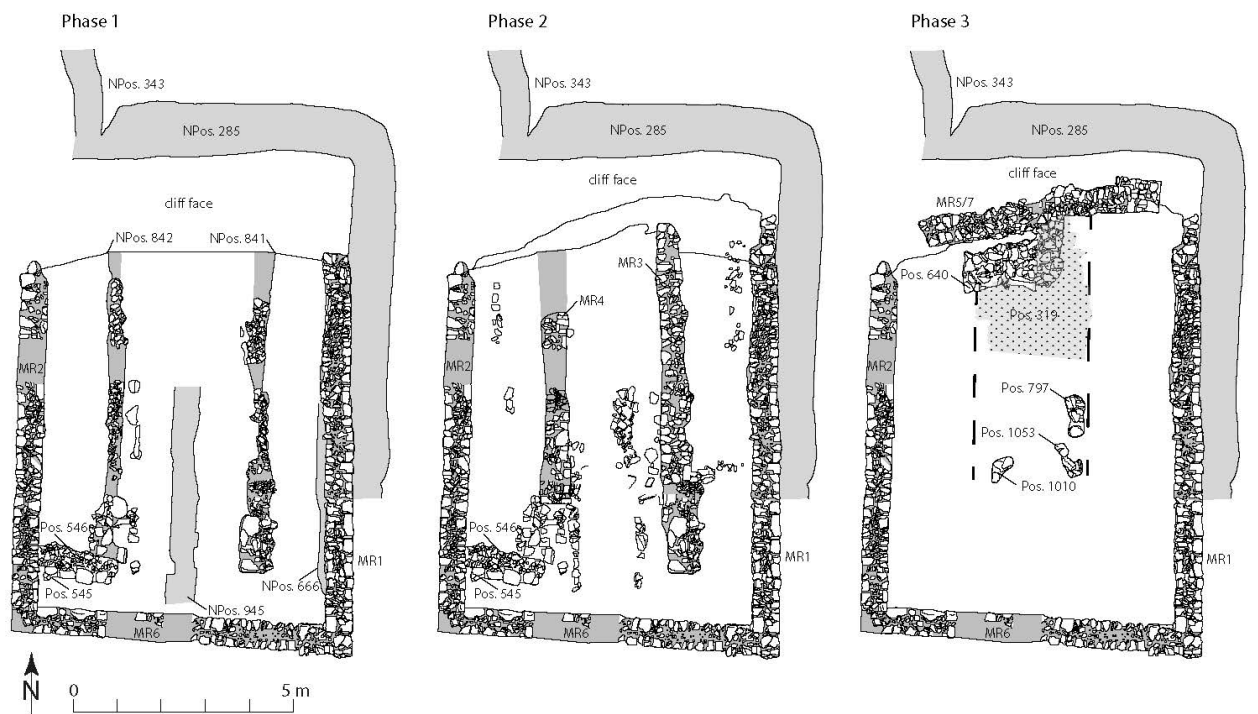

Fig. 4. Rapperswil-Jona, Kempraten, Zürcherstrasse 131:

Map of the individual occupation phases 1-3 of the Mithraeum (sc. 1:150, map: KASG)

wall MR6. Individual charred ${ }^{20}$ and uncharred ${ }^{21}$ boards preserved in situ suggest that the central aisle was covered with floor boards. These probably also covered drainage channel NPos. 945. The flowing water may have been visible for ritual purposes through openings in the floor.

Two elevated platforms (podia) of approximately $2 \mathrm{~m}$ in width were located on either side of the central aisle. The eastern podium was constructed by capping spoil heap 3, whose southern flank probably served as a ramp-like ascent. ${ }^{22}$ A narrow area in the south-eastern corner of the Mithraeum, which was not taken up by the central aisle or the ascent to the eastern platform, was interpreted as a passageway. No similar ascent was identified on the western platform, which had been specifically raised. Here, the southern edge of the elevated area (perhaps a reclining bench or an ascent? Pos. 546 and Pos. 545) marked off a zone of $0.7 \mathrm{~m}$ width, whose function remains unknown. ${ }^{23}$ Interestingly, Pos. 545 (perhaps the retaining construction of the platform or the substructure of a step?) had been made from stones very similar to those used to construct the inner section of southern wall MR6 opposite. Only parts of the retaining construction ${ }^{24}$ on the longitudinal sides of the reclining platforms and their

${ }^{20}$ Pos. 1094.

${ }^{21}$ Pos. 1086.

22 This area, interpreted as an ascent, was also finished in line with the retaining wall of the platform.

${ }^{23}$ At a later date (but still in either Phase 1 or 2), a shallow pit was dug in this area whose bottom fill contained a large number of animal bones. The upper, subsided fill layers contained the contents of a cupboard, which had probably collapsed in Phase 2.

${ }^{24}$ Pos. 549, Pos. 605, Pos. 568, Pos. 560, Pos. 1060, Pos. 809, Pos. 271, Pos. 1394, Pos. 1417 , Pos. 1377, Pos. 822. 
ascents survived. They consisted of stone, perhaps originally set in mortar, with round foundation stones for posts or pillars incorporated into the front row.

Undisturbed layers dating from Phase 1 survived only in the central aisle and beneath the platform faces of Phase 2. The composition of these layers suggested that the interior was at least partially destroyed by a conflagration in Phase 1.

\subsection{Phase 2}

The alteration work carried out at the beginning of Phase 2 largely retained the ground-plan and interior layout of Phase 1 (fig. 4, Phase 2). The east, west and south walls, or what was left of them, continued to be used. The north wall postulated for Phase 1, on the other hand, was demolished and the building extended northwards by approximately $0.6 \mathrm{~m}$ in the area of the central aisle and the eastern platform. This extension made it necessary for more of the bedrock to be removed, particularly to make way for the central aisle. This was not done in the area of the western platform, which resulted in a ground-plan for Phase 2 that was skewed in the north. The northern termination of the building did not survive.

The line and thus the width of the lateral platforms probably followed this northern termination of the building. The podia were widened by approximately $0.3 \mathrm{~m}$ due to the fact that the retaining constructions, now clearly constructed as walls (MR3 and MR4), had moved a little closer to the middle of the building. Behind these freestanding wall faces of the platforms, some of the bottom layers of the retaining constructions of Phase 1 remained intact. However, gaps were created by the alteration work in the upper parts and these were filled with soil that contained a lot of charcoal and bone. Altar fragments from the earlier occupation phase were reused as building materials for wall MR3 and another altar was visibly incorporated into it. ${ }^{25}$ Several small-scale intrusions were documented and interpreted as repairs and restorations carried out in Phase 2. Similar evidence of renovation work was also found in the central aisle. Joists ${ }^{26}$ for a boarded floor were identified at several levels in the central aisle. It could not be ascertained beyond doubt, however, as to whether the drainage channel NPos. 945 continued to be used or if the raised floor boards which rested on the joists were sufficiently protected from humidity without it.

No architectural changes appear to have been made to the south of the eastern platform. This may suggest that the ramp-like ascent, which was presumed to have existed in Phase 1, continued to be used. To the south of the western platform, however, the retaining wall of the elevated platform from Phase 1 was built over, although the course of the construction was retained and the ground-plan thus remained unchanged. Undisturbed charred occupation layers have survived from this phase, both on the reclining benches and in the central aisle. While this suggests that the interior had been destroyed by yet another fire, no actual burnt rubble was identified for this phase.

${ }^{25}$ Inv. 53.204.1602.001.

${ }^{26}$ Pos. 645, Pos. 650, Pos. 1073, Pos. 1106, Pos. 1108. 


\subsection{Phase 3}

The burnt occupation layers from Phase 2 caused the floor level to be raised significantly and the central aisle to be completely filled in. Again, the east, west and south walls appear to have survived the fire relatively unscathed and continued to be used. The north wall MR5/7, on the other hand, was completely rebuilt in stone (fig. 4). As part of this new construction and in preparation for a cult image and votive altars being erected, a multi-layered rubble foundation was introduced into the northern area of the former central aisle, which may have served as a working platform whilst the alteration work was ongoing. ${ }^{27}$ Several votive altars, an inscription and other temple furnishings that were no longer used in Phase 3 were deposited in the former central aisle directly south of the foundation mentioned. In addition, at least three smallscale foundations were installed in the area of the former central aisle (Pos. 797, Pos. 1053, Pos. 1010). Non-sunken structures from Phase 3 were found only in the northern section of the Mithraeum. Pos. 319 probably belonged to a gravel floor located in the former central aisle. The lateral platforms, on the other hand, which we may assume still existed, did not survive. Two joining fragments of a cult image ${ }^{28}$ and two altars dedicated to Mithras, ${ }^{29}$ however, suggest that the building still served as a Mithraeum. They were probably displayed in the northernmost section of the central aisle (see Chapter 4).

The distribution of the collapsed walls suggests that the building was probably erected in mixed construction. However, there were no obvious clues as to why the Mithraeum was eventually abandoned. Some of the collapsed rubble was removed at least from the northern section of the central aisle at an unknown date. The stone material might have been removed for use in the construction of a post-medieval mortar mixing plant, which was linked to large-scale alterations at the site.

\subsection{Exterior areas}

The division into phases, which was possible for the interior of the Mithraeum, did not apply to the exterior areas. This was not only due to the fact that the post-excavation work is still ongoing, but also because of the distinctly poorer state of preservation in that the exterior was much more affected by erosion than the building interior. Pits and pavings, which overlapped each other and were of a more recent date stratigraphically than the kiln-period use of the terrace, suggest that the exterior experienced several occupation phases probably linked to the Mithraeum.

A (foundation) trench NPos. 285 was definitely part of the Mithraeum. Whilst it was backfilled up to the bottom course of the wall, it remained partially open, thus serving as a drainage ditch running along the wall. The trench was dug into the rock

\footnotetext{
${ }^{27}$ This construction work demolished parts of the former western platform and the northern part of the central aisle.

${ }^{28}$ Inv. 53.204.0234.001 and Inv. 53.204.0234.002.

${ }^{29}$ Inv. 53.204.0230.001 and Inv. 53.204.0235.001.
} 
and extended beyond the northern edge of the building, from where it ran westwards following the rising terrain (figs 1 and 2). The resulting ditch NPos. 285 probably drained off both the water that seeped out of the slope when it rained and the water which gathered in a natural groove NPos. 343 that ran down the slope. At this stage it cannot be determined whether this ditch had other functions such as delimiting the sacred area (temenos).

\section{FINDS}

The cleaning, restoring and cataloguing of the finds is still ongoing and the detailed analysis of most of the categories of finds is still under way. Moreover, the finds (except for the altars and relief fragments) have not yet been linked to the different construction phases, so that it will only be possible here to give a preliminary, cursory overview on the artefacts.

A total of at least eight altars, five of which bore discernible inscriptions, another fragment of an inscription, two fragments of a cult image and other furnishings, which cannot yet be described in more detail, will be examined as part of the planned specialist study.

The furnishings of Phase 3 were represented by a completely preserved steatite altar, ${ }^{30}$ an altar fragment ${ }^{31}$ and two joining fragments of a sandstone cult image ${ }^{32}$ (fig. 3).

The interpretation of the scene depicted in the cult image is hampered by the poor state of preservation of the surfaces of the sandstone, which, as a material, is prone to weathering (fig. 3). A larger than life-sized depiction of the head and shoulders of a man wearing a Phrygian cap is clearly visible on the left edge of the image. The joining fragment shows a bulging part, most definitely not the arm of Mithras, which means that a depiction of the tauroctony can be excluded.

The completely preserved steatite altar measures $22 \mathrm{~cm}$ in height, exhibits the dedication INVICTO MITRE and was located right beside the cult image (fig. 3). This is the only explicit mention of Mithras; the other dedications were INVICTO or DEO INVICTO.

Besides the steatite altar, a significantly larger sandstone altar dedicated to INVICTVS was also part of the preserved furnishings of the Mithraeum in Phase 3 of its use. The exposed surfaces of the sandstone altar were severely weathered. Fortunately, the altar fragment was found lying on its inscribed side, which led to the dedication on the cornice and the top three or four lines of the inscription being preserved.

Another sandstone altar of similar size was part of the furnishings during Phase 2 of the Mithraeum. ${ }^{33}$ The upper left corner of the altar was reused as a building block for north wall MR5/7 when the Mithraeum was rebuilt in Phase 3, whilst the otherwise

\footnotetext{
${ }^{30}$ Inv. 53.204.0230.001.

${ }^{31}$ Inv. 53.204.0234.001.

${ }^{32}$ Inv. 53.204.0234.001 and Inv. 53.204.0234.002.

${ }^{33}$ Inv. 53.204.0314.001 and 53.204.0715.001.
} 
almost complete altar was deposited in the central aisle together with other stone fittings. ${ }^{34}$ Only one sandstone altar survived in its original location built into the front face of a podium, although its severely weathered surface did not bear or no longer bears an inscription.

Two altar fragments reused as building blocks in the eastern platform wall face MR3 probably belonged to the furnishings of Phase 1. Joining fragments from both altars were found amongst the rubble from the collapsed eastern external wall and in the central aisle.

The informative value of the more abundant categories, i.e. the pottery, small finds and archaeobiological remains, must not be underestimated. An assemblage of more than 500 coins, for instance, not only allows us to date the individual occupation phases, but their distribution may also enable us to draw conclusions with regard to the use of the different areas within the Mithraeum and to their purpose as sacrificial offerings or decorative elements.

The high proportion of poultry and young animal bones (particularly of pigs) amongst the zoological finds and significant numbers of ceramic and steatite beaker fragments undoubtedly attest to the consumption of meals as part of the cult and the high quality of the food served. One particular steatite beaker with a dedication, which has not yet been fully deciphered, to DEVS INVICTVS in cursive script running in three lines around the beaker is worth particular mention.

The absence of serpent-decorated vessels and incense burner amongst the pottery is striking. This is all the more surprising given the fact that such vessels are known to have been made at the vicus and that the practice of incense offerings and the use of serpent-decorated vessels are considered common elements of Mithraism. ${ }^{35}$ Another striking factor was the small number of lighting fixtures found such as oil lamps or fatwood holders.

A special category amongst the Kempraten finds were more than 50 rock crystal fragments and hundreds of crystal chips recovered from the central aisle. Only one other Mithraeum is known where rock crystal was proved to have been of ritual importance: more than 80 fragments found at the Martigny Mithraeum had been attached to the ceiling above the cult image to symbolise stars reflecting the light of the lamps below. ${ }^{36}$ However, rock crystal fragments and chips were also interpreted

${ }^{34}$ At least one other votive inscription (Inv. 53.204.0716.001) was associated with Phase 2. The fact that four other sandstone fragments were bigger than the building blocks used in the Mithraeum (though some of their surfaces did not survive) suggests that they can perhaps also be interpreted as having been part of the furnishings. A slab of verrucano slate (Inv. 53.204.0714.001) and a fragment of a steatite altar (Inv. 53.204.0486.001) probably also belonged to this group.

${ }^{35} \mathrm{Cf}$. for instance BIRD, J.: Incense in Mithraic ritual: the evidence of the finds. In Roman Mithraism (n. 12) 192. - However, neither serpent-decorated nor smoking vessels were found at the Mithraeum at Orbe-Boscéaz; see LugINBÜHL, T.: Du mobilier aux rites. In PAUNIER-LUGINBÜHL: La villa romaine d'Orbe-Boscéaz (n. 12) 289-292; Jacques Monnier, Archaeology Department of Canton Fribourg, pers. comm.

${ }^{36}$ MEISSER, N. - WiBLE, F.: Typologie, origine et usage du cristal de roche du mithraeum de Forum Claudii Vallensium/Martigny (Valais). In DAUDRY, D. (éd.): Bulletin d'études prehistoriques et archéologiques alpines. Aoste 2007, 352. 
as votive offerings in the ritual cave at Zillis. ${ }^{37}$ The analysis of the distribution of the rock crystal fragments from Kempraten, whose precise positions were recorded on site, will hopefully help to determine their function.

Clay balls with diameters of 1.6 to $1.9 \mathrm{~cm}$ and incised numbers, similar to those found at the Magna Mater sanctuary at Kempraten, probably played some sort of role in the ritual acts. ${ }^{38}$ The Kempraten Mithraeum also yielded one ball made of a nonferrous metal and one sandstone ball which, however, bore no number, both of which were of the same size as the 34 ceramic balls. ${ }^{39}$

There are no parallels at any of the other Mithraea for the presence of 60 boars' tusks which were found in and around the Kempraten Mithraeum. The only evidence pointing to the possibility that boars' tusks may have played some sort of role in Mithraism that we are aware of was found at Bornheim-Sechtem near Bonn. ${ }^{40}$

Weapons and knives are quite often found at Mithraea. ${ }^{41}$ The Kempraten site also yielded two arrowheads, two lanceheads and at least one knife. Knives must not be seen exclusively as objects of ritual importance, though they are often interpreted as representing Mithras' dagger. Arrowheads and lanceheads may point to initiation rites or were perhaps used for the purpose of visualising Mithraic legends, specifically the water miracle or the hunting scene.

\section{DATING}

The preliminary dating of the Mithraeum is based solely on the coins that have been identified so far. ${ }^{42}$ The large proportion of 3rd century AD coins suggests that the Mithraeum existed from no later than the end of the 3rd century. Since coins generally do not occur in large numbers in Mithraea before the late 3 rd century ${ }^{43}$ and because the layers of the earlier phases at Kempraten were severely disturbed by later

${ }^{37}$ EBnÖther, C. - Deschler-ERB, S. - PETER, M.: Le vase annulaire aux serpents de la grottesanctuaire de Zillis (canton de Grisons, Suisse) dans son contexte. In RIVET, L. (éd.): Actes du Congrès de Nyon, 14-17 mai 2015. Marseille 2015, 181-186, 183.

${ }^{38}$ See the article by Pirmin Koch in this volume, DOI: 10.1556/068.2018.58.1-4.34. - Clay balls with incised numbers were also found at the Gallo-Roman sanctuary on Martberg hill and at the Mithraeum of Frankfurt-Heddernheim; NICKEL, C.: Martberg und Karden an der Mosel: Keltischer und römischer Kult. Bonner Jahrbücher 58 (2009) 113-114.

${ }^{39} \mathrm{On}$ the presence and interpretation of similar but much larger stone balls at other Mithraea cf. Huld-Zetsche, I: Der Mithraskult in Mainz und das Mithräum am Ballplatz [Mainzer Archäologische Schriften 7]. Mainz 2008, 109-117.

${ }^{40}$ Deposition of a fragment of a sculpture, a coin of Valentinian I, a complete colour-coated beaker, a fragment of slag, a yellow lead-glazed sherd with a moulded Cautes appliqué and a tusk of a wild boar in a tufa rock shaft; see UlBeRT, C. - WulfMEIER, J.-C. - HulD-ZETSCHE, I.: Ritual Deposits of Mithraic Cult-vessels: New Evidence from Sechtem and Mainz. Journal of Roman Archaeology 17 (2004) 360 .

${ }^{41}$ SchatzManN, A.: Möglichkeiten und Grenzen einer funktionellen Topographie von Mithrasheiligtümern. In Roman Mithraism (n. 12) 11-24.

${ }^{42}$ At this stage, roughly four out of five coins have been identified by Markus Peter from the Swiss Inventory of Coin Finds in Bern.

${ }^{43}$ SAUER, E.: Not just small change - Coins in Mithrea. In Roman Mithraism (n. 12) 336. 
alterations, it will not be possible to arrive at a reliable date for the construction of the Mithraeum until the study of all the finds from the sanctuary and the adjacent lime kilns has been completed.

The most recent coins (Valentinian and Theodosian Aes) were already in circulation before the alterations for Phase 3 took place, which suggests that the Mithraeum was abandoned no earlier than the late 4 th century $\mathrm{AD}$ and perhaps remained in use until the 5 th century AD. ${ }^{44}$

\section{CONCLUSION AND OUTLOOK}

It came as a great surprise when a Mithraeum was discovered in the summer of 2015 during excavations mounted on the edge of the Kempraten vicus, although a peripheral location is characteristic of such sanctuaries. Both Mithraea at Güglingen, for example, were situated $70 \mathrm{~m}$ from the road and the Martigny Mithraeum was also found on the edge of the settlement. ${ }^{45}$ Moreover, it is not unusual for Mithraea to be discovered near other, often supra-regional, sanctuaries. ${ }^{46}$ Perhaps it was thus not a coincidence that the Kempraten Mithraeum was built near the Magna Mater sanctuary at Kempraten-Seewiese. The topographical situation also favoured the construction of a Mithraeum in that the deposits on the rock surface at the foot of the slope were easily removed and the subsoil shaped prior to building the sanctuary. Due to the later alterations, however, it remains unknown whether the rock face to the north remained visible during the first two construction phases or whether it was hidden by a wall. The use of the rocky environment for the sanctuary is easily put into context with Mithras' birth from a rock, the legendary water miracle and Mithras' central deed, the slaying of a bull in a cave. The water seeping out of the sandstone was in fact accessible in the central aisle at least during the first two phases, which shows that the water miracle could have been recreated at the site.

Evidence of Mithraism in the wider region is quite rare (fig. 5). Besides the man-made sanctuaries at Orbe and Martigny in western Switzerland mentioned earlier, Mithras was possibly also worshipped in the natural cave at Zillis and the same is assumed for two caves at Avenches/Aventicum. ${ }^{47}$ Moreover, individual finds

${ }^{44}$ SAUER (n. 43) 340.

${ }^{45}$ Güglingen: KortüM, K. - Neth, A.: Mithras im Zabergäu. Die Mithräen von Güglingen. In SchmidT, S. (Hrsg.): Imperium Romanum - Roms Provinzen an Neckar, Rhein und Donau. Stuttgart 2005, 225; Martingy: WIBLÉ (n. 12) 146; see also the Biesheim Mithraeum: FoRTUNÉ, C.: Le mithraeum, une fouille ancienne revisitée. In Oedenburg. Vol. 2 (n. 15) 234.

${ }^{46}$ For example at Biesheim (FORTUNE [n. 45]) or Martigny (WIBLÉ [n. 12] 146); for more general statements, see also DuBOIS, Y.: Un sanctuaire aux marges de la sphère publique: le mithraeum (état des lieux). In Boisleve, J. - JARDEL, K. - TENDRON, G. (eds): Décor des édifices publics civils et religieux en Gaule durant l'Antiquité, $I^{e r}-V^{e}$ siècle. Actes du Colloque de Caen 7-8 avril 2011. Mémoires de l'Association des publications chauvinoises 45. Chauvigny 2012, 426.

${ }^{47}$ Orbe: MonNIER: Un dieu (n. 12), LUGINBÜHL-MONNIER-MÜHLEMANN (n. 12) and MONNIER: Le mithraeum (n. 12); Martigny: WIBLE (n. 12) 146-166 (with earlier references); Zillis: RAGETH, J.: Ein 


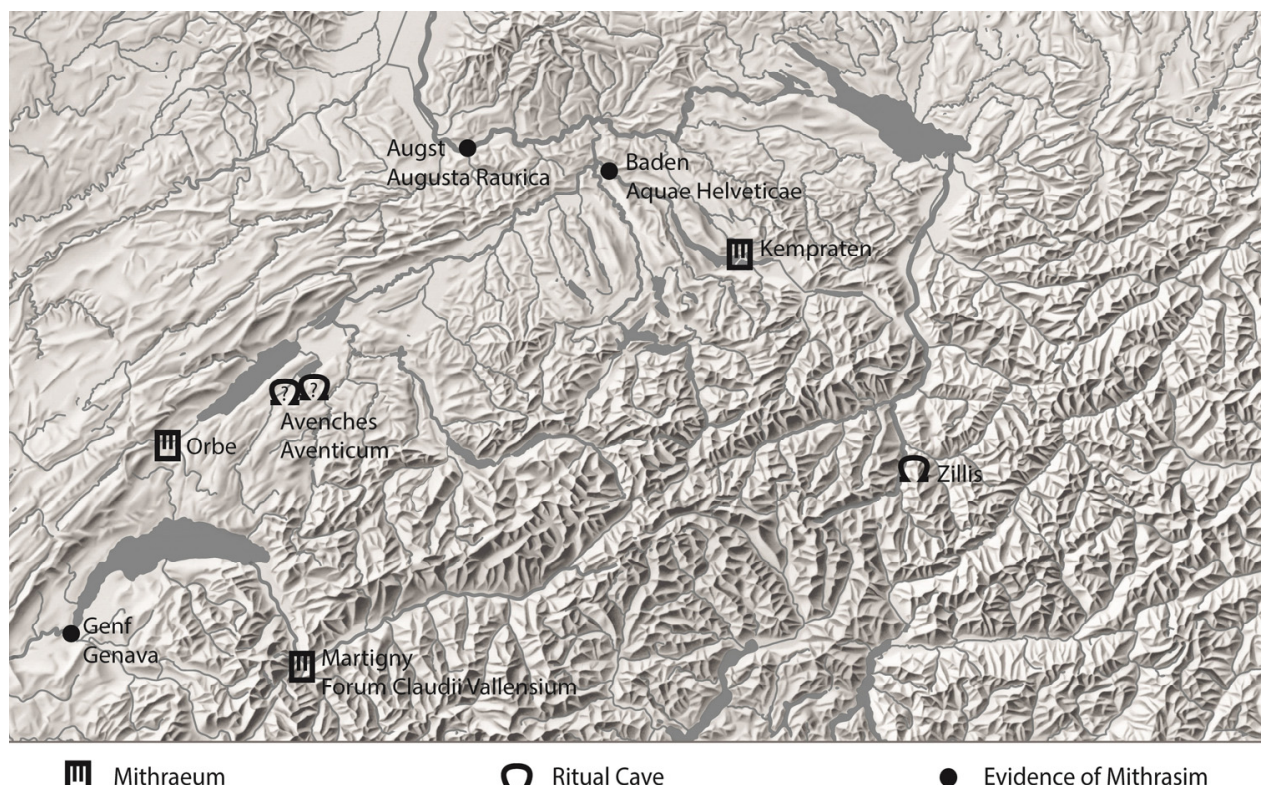

Fig. 5. Distribution map of all known Mithraea, ritual caves and evidence of the worship of Mithras in what is today Switzerland (sc. 1:3'000'000, map: KASG; basis for the map: geodata $\mathbb{C}$ swisstopo)

and evidence pointing to the dedication to Mithras have come to light at Augst/Augusta Raurica, Baden/Aquae Helveticae and Geneva/Genava. ${ }^{48}$ This sparse distribution of sanctuaries dedicated to Mithras is consistent with that seen in the Gallic provinces in general. ${ }^{49}$ The evidence along the limes on the Rivers Rhine, Main and Danube, on the other hand, is much more abundant. ${ }^{50}$ Naturally, such distribution maps are also a reflection of the state of research in each individual region. Moreover, the Kempraten

spätrömischer Kultplatz in einer Höhle bei Zillis GR. Zeitschrift für Schweizerische Archäologie und Kunstgeschichte 51 (1994) 141-172, LIVER, A. - RAGETH, J.: Neue Beiträge zur spätrömischen Kulthöhle von Zillis - die Grabungen von 1994/95. Zeitschrift für Schweizerische Archäologie und Kunstgeschichte 58 (2001) 111-126 and EBNÖTHER - DeSCHLER-ERB - PETER (n. 37); Avenches: DE PURY-GYSEL, A.: Avenches - Aventicum, Hauptstadt der Helvetier. Zum Forschungsstand 1985-2010. Bericht der Römisch-Germanischen Kommission 93 (2012) 170-177.

${ }^{48}$ See overviews with detailed lists of references in DRACK, W. - Fellmann, R.: Die Römer in der Schweiz. Stuttgart 1988, 251-253 and BossERT-RADTKE, C.: Die figürlichen Reliefs und Rundskulpturen aus Augst und Kaiseraugst [Forschungen in Augst 16]. Augst 1992, 110-111 (most notably with a critical review of the inscription and sculpture in the round from Nyon/Colonia Iulia Equestris, which, following the excavator E. Pelichet, was interpreted by W. Drack and R. Fellmann as evidence of a Mithraeum: PELICHET, E.: Fouille archéologique à Nyon, en 1958. Jahrbuch der Schweizerischen Gesellschaft für Urgeschichte 47 [1958-1959] 117-121).

${ }_{50}^{49}$ DuBoIS (n. 46) 426 and fig. 1.

${ }^{50}$ WiTsCHEL, C.: Die Ursprünge des Mithras-Kults. Orientalischer Gott oder westliche Neuschöpfung? In Imperium der Götter. Isis - Mithras - Christus. Kulte und Religionen im Römischen Reich. Begleitband zur Ausstellung im Badischen Landesmuseum in Karlsruhe vom November 2013-Mai 2014. Stuttgart 2013, 210 and figs on pp. 206-207; DuBOIS (n. 46) 426. 
example clearly shows how important it is for the discovery of Mithraea to carry out consistent monitoring of construction projects located outside of the actual settlement perimeters. Nevertheless, the distribution probably does not merely represent different states of research, but also reflects historical reality. This may have been the result of greater mobility of certain groups of people along a border, which could have significantly contributed to the spread of the cult. The hinterland, in contrast, appears to have been less affected by the new belief system.

The Archaeology Department of Canton St. Gallen is aware of the importance of the Kempraten Mithraeum, which has been excavated using up-to-date methods and in keeping with interdisciplinary research questions. A preliminary project was launched in the summer of 2016 whilst the post-excavation work and the completion of the excavation reports was still ongoing. It aims first and foremost to prepare the numerous archaeobiological and micromorphological samples, restore the finds and identify the coins. This will constitute the groundwork for the planning of an interdisciplinary study which will be carried out by a team of specialists from various fields of research with the aim of publishing a comprehensive analysis.

\section{ACKNOWLEDGEMENTS}

Numerous colleagues visited the excavation and provided invaluable input by discussing the findings and making concrete suggestions. In particular we would like to mention Christa Ebnöther and Johannes Wimmer (University of Bern); Örni Akeret, Sabine Deschler-Erb, Christine Pümpin and Philippe Rentzel (University of Basel); Rahel Ackermann (Swiss Inventory of Coin Finds, Bern); François Wiblé (Martigny); Pirmin Koch and Martin Schindler (KASG). We would also like to thank Sandy Hämmerle (Galway) for the English translation of this article.

Sarah Lo Russo - Regula Ackermann - Hannes Flueck

Kantonsarchäologie St.Gallen

St.Gallen

Switzerland

sarah.lorusso@unibas.ch

regula.ackermann@sg.ch

hannes.flueck@archaeologe.ch

Markus Peter

Abt. Archäologie der Römischen Provinzen

Institut für Archäologische Wissenschaften

Universität Bern

Bern

Switzerland

markus.peter@iaw.unibe.ch 
